Article

\title{
Sustaining Sanak Island, Alaska: A Cultural Land Trust
}

\author{
Katherine L. Reedy-Maschner ${ }^{1, *}$ and Herbert D. G. Maschner ${ }^{1,2}$ \\ 1 Department of Anthropology, Idaho State University, Stop 8005, Pocatello, ID 83209, USA; \\ E-Mail: maschner@isu.edu \\ 2 Idaho Museum of Natural History, Idaho State University, Stop 8096, Pocatello, ID 83209, USA \\ * Author to whom correspondence should be addressed; E-Mail: reedkath@isu.edu; \\ Tel.: +1-208-282-2629; Fax: +1-208-282-4944.
}

Received: 25 July 2013; in revised form: 9 October 2013 / Accepted: 10 October 2013 / Published: 17 October 2013

\begin{abstract}
Sanak Island is the easternmost of the Aleutian Islands and was inhabited by the Aleut (Unangan) peoples for nearly 7000 years. The past few centuries of Sanak Island life for its Aleut residents can be summarized from ethnohistoric documents and extensive interviews with former residents as shifting local-global economic patterns beginning with the sea otter fur trade, followed by cod and salmon fishing, fox farming, and cattle ranching through waves of Russian, American, and Scandinavian authority and/or influence. As the industries changed and the island absorbed new peoples with new goals, Aleut identity and practices also changed as part of these shifting economic and social environments. Sanak Island was abandoned in the 1970s and although uninhabited today, Sanak Island is managed as an important land trust for the island's descendants that serves local peoples as a marine-scape rich in resources for Aleut subsistence harvesting and as a local heritage site where people draw on the diverse historical influences and legacies. Further, this move from an industrial heritage to contemporary local subsistence economies facilitated by a commercial fishing industry is a unique reversal of development in the region with broad implications for community sustainability among indigenous communities. We find that by being place-focused, rather than place-based, community sustainability can be maintained even in the context of relocation and the loss of traditional villages. This will likely become more common as indigenous peoples adapt to globalization and the forces of global change.
\end{abstract}

Keywords: Aleut; Sanak Island; fisheries; sustainability; resilience; historical ecology; land trust 


\section{Introduction}

The Sanak Islands are a small archipelago located about $50 \mathrm{~km}$ south of the southern tip of the Alaska Peninsula within a rich marine ecosystem that forms the foundation of the Aleut (Unangan) world (Figure 1). The Aleut have inhabited these islands for thousands of years as subsistence sea mammal hunters and fishermen [1-6]. During the past two and a half centuries the Sanak Islands were at the heart of the global sea otter trade, then became the center of the Pacific cod fishing industry, and later hosted experiments in fox farming and cattle ranching, but today they are uninhabited. These islands have had a complex history involving major economic shifts under waves of Russian, American, and Scandinavian authority and influence, which over time have shaped the landscape and the identity of the Aleut [7,8]. Sanak Island was rapidly industrialized and its landscape and ocean used intensively, but now it experiences a local subsistence economy from a distance that is only possible using equipment from the local commercial fishing industry. Here, we attempt to elucidate the dynamics of the transition from one socioeconomic system to another within various social and political contexts to reveal the historical trajectory leading up to human displacement from the islands and identify how the Aleut have maintained a social, political, and economic connection to the now vacant island. In doing so, we present a model for how people maintain place-based identities after displacement. Displacements have been frequent throughout human history and are expected to continue in the future given climatic changes such as rising sea levels [9], natural and technological disasters [10], political conflicts and forced relocations through development [11], among many. We show how this particular case study has unique local and political features that support a place-focused identity, but that there are broader lessons for how a cultural land trust can be fashioned out of such displacement.

The Sanak Island Biocomplexity Project was a broad multidisciplinary investigation of humans within the Sanak ecosystem using the islands as a laboratory in the Aleut world. The project considered humans as engineers of the natural environment through all spatial and temporal scales, actively shaping the landscape as users. As part of this team, we investigated the settlement history of the region as part of an open and dynamic system of regional interaction, and documented the relationship to this place in the context of the construction of Aleut identity and society. This requires identifying changes in the distribution, density and quality of subsistence and commercial resources, and how human society and the environment have been mutually constructed over time. We also investigated the present relationship to this island for how its stewards and former residents conceptualize, use, shape, and protect their lands. In this study we summarize the history of the Aleut in the North Pacific ecosystem, and situate their story within broader anthropological questions of sustainability and the political nature of place to show how land can be conceptualized as a source of power and identity to marine-based, coastal communities (see [12]).

Places, landscape, and place-based identities are of interest to indigenous communities encountering relocation, development and land claims (e.g., [13-17]). Many people have become separated from their land or "deterritorialized" [18,19]. This displacement and disruption can be traumatic, especially for those who have never been able to live in their home village (e.g., [20]). Many arctic and north Pacific communities are facing relocation due to climate change and socioeconomic struggles (e.g., [21,22]). These communities have often been in flux; during land claims negotiations in Alaska in the 1960s, 
people had already moved off many islands and out of villages because of economic change, such as the villages of Unga and Belkofski in the Aleutian region, and King Island in the northern Bering Sea [23], yet still retained a place-based identity in the decades to follow. This paper shows that the legacy of this disruption can be largely positive, hopeful, and with strong attachments, partly through treating the formerly occupied island and villages as cultural land trusts. Native corporations were granted lands and maintain them for the benefit of their shareholders in the way of banking lands and their resources, actively investing in their development and care, and preserving its heritage that has shaped the former residents' identity. In the Aleutian region, several tribes live wholly outside their lands and former villages, and are physically located in other villages administrating their lands from a distance, and it is these groups who strive to maintain ancestral connections to their lands and create a vision for their future. In this case study, we show how people maintain place-based identities after displacement, and continue to do so generations later, by describing our model of what we consider a "land trust".

Figure 1. Map of Alaska (upper), and the project area (lower), showing the location of Sanak Island.

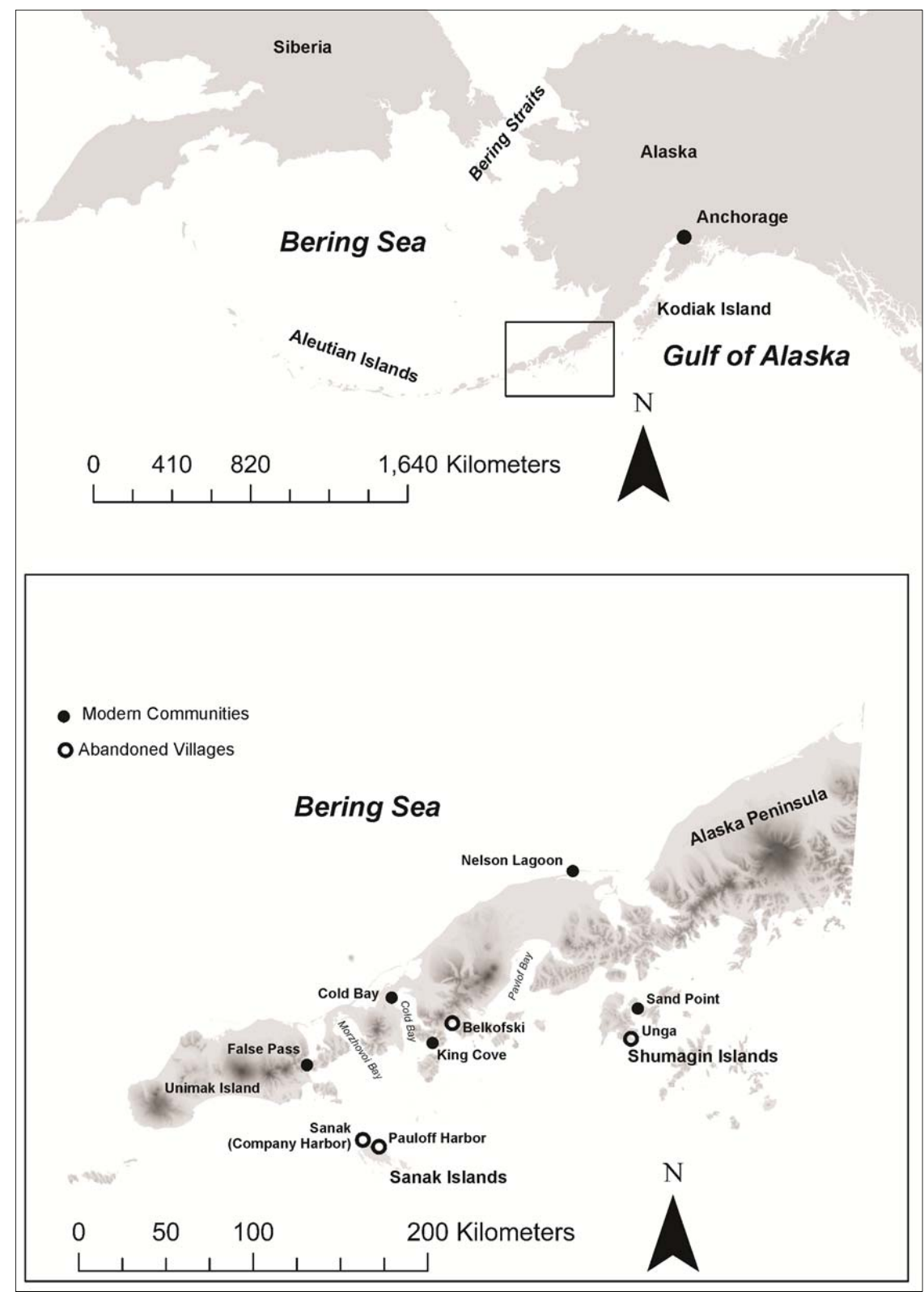


Sanak Island is the largest of the archipelago at $25 \mathrm{~km}^{2}$ and is owned by the Sanak Corporation, a village corporation created following the Alaska Native Claims Settlement Act of 1971 and headquartered in the nearby Aleut village of Sand Point (Figure 2). The other islands (Caton, Elma, Long, among numerous smaller islands and islets) are under the jurisdiction of the U.S. Fish and Wildlife Service because they were not lands chosen by the Sanak Corporation under the settlement act, and are now part of a designated wilderness area. Sanak Island is home to cattle, horses, foxes (until 2007), birds and sea mammals, and until about 1980, humans. The abandonment was a local decision following economic shifts and failures when the last inhabitants left for the larger villages of Sand Point, False Pass, Nelson Lagoon, and King Cove, which had become commercial fishing centers. Despite its desertion and federal control of the surrounding islands and waters, we will show how Sanak remains firmly within the Aleut political, social, and economic world.

Figure 2. Map showing the place-names and historical locations of people and activities as identified by the former residents of Sanak Island. These data represent the deep connection of the descendants of the island.

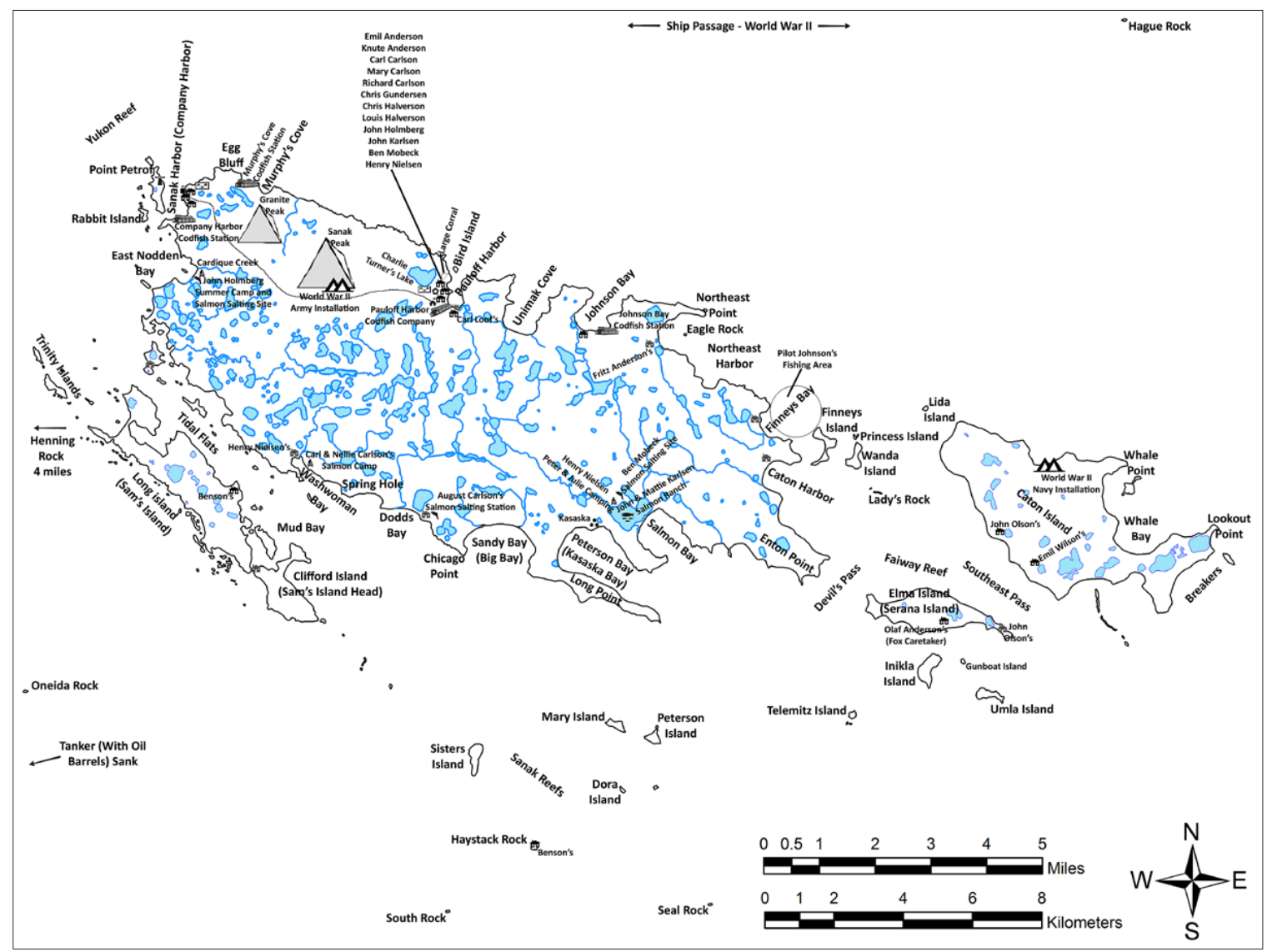

The greater North Pacific/southern Bering Sea region experiences large scale (industrial), small scale (local commercial), and subsistence harvesting of marine species, with commercial activities dating back at least two centuries and subsistence for at least 10,000 years. Today, many of these species are declining in numbers, which is leading to rapid policy changes that are ultimately aimed at these species' conservation and sustainability, but shape and regulate human behavior as well. Native villages are culturally and economically threatened by fluctuations and declines of key species and the 
regulation of human harvesting around them. How then do we sustain salmon, groundfish, birds, sea mammals, among many marine and terrestrial species, as well as the peoples and cultures who depend on them for economic stability and sociocultural identity? More specifically, how do we keep the Aleut in the Aleutians?

This is neither a flippant nor a rhetorical question. Transient fishermen continue to increase in the area, outnumbering or replacing resident Aleut fishermen in the salmon, cod, pollock, halibut, crab, and herring fisheries. Populations for some villages grow steadily while others are on the verge of abandonment. The largest Aleut "village" today is Anchorage, the largest city in Alaska, and the product of a continuous and one-way diaspora out of rural Alaska to the city. Can this one island group, and the Sanak Aleut who shaped these islands and themselves within it, enlighten us about indigenous community sustainability in the Aleutians, the Pacific, and across the planet? We will show that for the Sanak Islanders, they are solving their loss of a physical community on Sanak Island through their own dynamic interactions with this socially, politically, and economically important island. As we will show, the Sanak Aleut have figured out ways to be place-focused when they cannot be place-based, and do so through investing in the island's physical health, exploring its economic utility, documenting its historical value, and opening it up for access to the broader Aleut community. This has implications for all peoples who seek community viability and sustainability in the face of possible displacement due to global climate and/or political change.

\section{Background}

This study centers on the importance of sustaining Sanak Island in the historical construction and contemporary maintenance of Aleut identity. Collectively, the Sanak research team took the approach that social history requires recounting the natural history, and vice versa, an approach that is common in sustainability science [24,25]. Landscapes are the material manifestations of social-environmental interaction in which there are multiple ongoing relationships between humans and nature over time; some are compatible and some are conflictive. The research team conducted archaeological surveys and test excavations across the island, with $100 \%$ of the landscape surveyed for villages, fish camps, hunting camps, and other site categories. Over 120 archaeological sites that could be affiliated with both historic and ancient Aleut peoples were identified. Over a half million bones from nearly 100 different mammal, bird, and fish taxa were collected in excavations. This research demonstrated a 7000-year occupation of the island by the Aleut. It also showed that the Aleut were often required to respond directly to climate-driven changes in marine productivity and changes in the Aleut population correlated closely with changes in the overall productivity of the marine-scape [3,26,27]. Ecological surveys of the terrestrial and intertidal landscapes and near-shore food-web analyses show that certain components of the ecosystem, and certain species interactions, may have been a byproduct of human ecosystem engineering as the local peoples intensely harvested resources over thousands of years [3,28-30]. Unexpectedly, there is no evidence that the local peoples put any harvesting pressure on key species over the last 4500 years, and no evidence of over-exploitation [31,32], although the Aleut did expand their diet breadth down the food chain during periods of decreasing marine productivity [33]. 
There are several comprehensive ethnographic and ethnohistoric studies about the Aleut [1,7,34-43], but few with reference to the Sanak Islands specifically (e.g., [44-48]). Nonetheless there is enough evidence to show that virtually every major historical Aleutian event touched these islands, from infamous Russian-Aleut encounters to Captain Cook's forays into the region, making Sanak something of a "vertical slice" of Aleutian historical and contemporary life. Furthermore, we conducted extensive interviews with former residents of Sanak, their descendants, and Aleut fishermen who fish Sanak's waters and hunt on the island today (Figure 3). These Aleuts, now living in the nearby communities of Sand Point, King Cove, Nelson Lagoon, and False Pass, as well as in Anchorage, have a detailed knowledge about the landscape and waters of the region and recounted stories and traditions about the island that rooted them to place. Through an extensive review of ethnohistoric documents and new interview data with former residents of Sanak Island, we have a detailed picture of the local history, demographics and settlement, politics, Aleut family dynamics, along with the historic and modern subsistence and commercial uses of the island and surrounding waters.

Figure 3. A commercial fishing boat owned by a member of the Sanak Corporation and Pauloff Harbor Tribe in Pauloff Harbor on Sanak Island. Part of the abandoned town site is in the foreground.

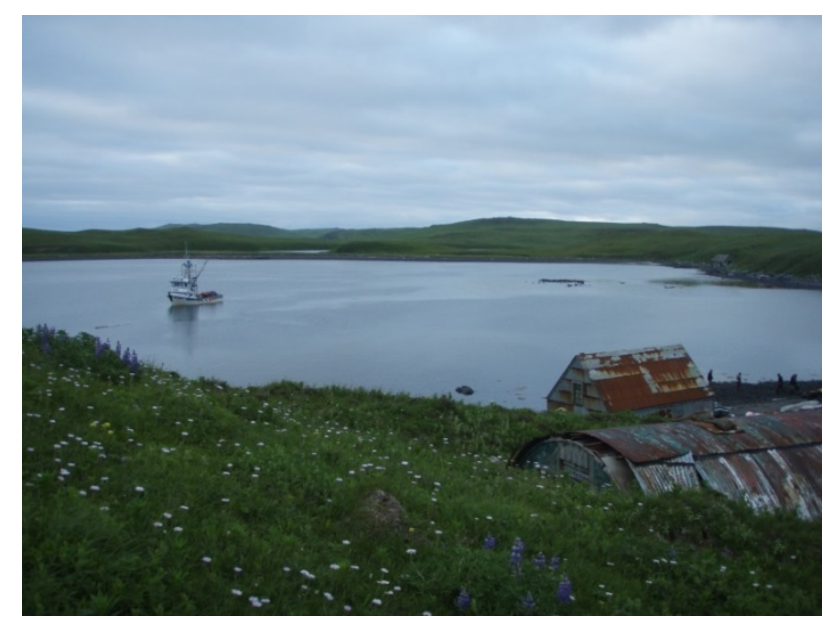

These combined data are used to carry the reader through the major historical time slices of Sanak Island highlighting population shifts, regional interactions, resource use, and Aleut sociocultural responses to changes. The purpose is to describe the historical trajectory that created the present conditions of separation, demonstrate the heritage resources the current population draws on for identity and attachments, and describe the transition from a place-based to a place-focused identity through the creation of a cultural land trust. Sanak Island witnessed intensive development of a succession of industries, each followed by periods of relatively low use, and finally recourse to subsistence use from distant villages. The past few centuries of Sanak Island life can be summarized as shifting local-global economic patterns surrounding sea otters, cod, salmon, fox farming, and cattle ranching under waves of Russian, American, and Scandinavian authority and/or influence, followed by local commercial and subsistence fisheries. This move from an industrial heritage to contemporary local subsistence economies facilitated by a commercial fishing industry is a unique reversal of development in the region, and has strong implications for the dialogue on heritage and sustainability 
in the Pacific and arctic. Although uninhabited today, Sanak remains an important center for local people, rich in resources for Aleut subsistence harvesting.

\subsection{Place-Based Identities}

The concept of place in human society has been debated for its meaningfulness and anthropological utility. Appadurai [49] offered critiques for how anthropologists have "incarcerated" indigenous people in places and denied their regional and global interactions to create conveniently bounded elements of difference in locations. Gupta and Ferguson argued that there are no places until they are constructed and imagined by people, also challenging the idea that cultures are "discrete, object-like phenomena occupying discrete space” [50]. They argued that the organization of identity around locality is increasingly obsolete and anthropologists must adjust their thinking about cultural space.

Thornton [17], however, emphasizes the importance of concrete locations to senses of place and their changing meanings for the Tlingit. He shows how Native Alaskans have long imparted cultural, spiritual and ecological significance to their surroundings. Ganapathy [51] recently reviewed a range of popular ways in which Alaska is imagined from afar and how these framings of natural purity or resource development potential are experienced locally. Ganapathy effectively argues that the ascribed definitions and imaginative processes of Alaskan landscapes become entwined with the local significance of place for its Native peoples. Local people assert their own attachments to land bases and senses of belonging to particular locations within these other concepts of their surroundings.

As will be shown, for the Aleut people, the physical place of their islands matters, and the geography, stories and biographies of the people and landscape, resources it offers, and shared symbolic elements are fused together in the construction of a cultural landscape. Foreign expansions into the region were underwritten by economic valuations that are now seen as having merged with local identities. Sanak Aleuts are now revisiting historical influences on their island and people, assessing local desires and uses for the island, and creating a vision for their place that supports a Sanak islander identity from a distance.

\subsection{Human Economic and Ecological Sustainability}

Theories considering the roles of humans in their environments have ranged from studies of closed societies that include analyses and critiques of "original affluent societies" in which hunter-gatherers were seen to have balanced work and leisure relative to their resources [52,53], or the "giving environment" in which humans are integrated in sharing relationships with the natural world [53], to using natural sciences such as measuring calorie production and consumption [54] and cost-benefit analyses of "optimal foraging theory" [55]. In 1974, the term 'original ecologists' was applied in the popular media to Laughlin's description of the Aleut because of their abundant environment, showing how they are "the world's best example of how man fits in the natural system" [56]. However, the scale of fisheries use and development in the Aleutians has dramatically expanded since that time and new agents are modifying the economic life and environment of the region. In recent decades, theories and debates shifted towards emphasizing people's experiences in larger political and ecological systems recognizing global constraints, resource conflicts, policymaking, power differentials, identity and place, and an expanding indigenous rights movement (e.g., [57-59]). In the 
arctic, the challenge for so many communities is maintaining a sense of place, economic stability, and identity, often couched in terms of sustainability, resilience and vulnerability.

Sustainability in the Pacific and arctic has been defined as building diverse subsistence and commercial economies that are compatible with local human-animal-environmental relationships, strong leadership that champions community self-determination and control over lands and politics, and education that reinstates indigenous knowledge and supports future generations in traditional homelands [60,61]. In many cases in Alaska, villages are striving to achieve a list of goals and conditions. It has been shown, however, that many villages that have "achieved" this list are still vulnerable and disintegrating due to externalities, and those villages aspiring to these same goals will still likely fall short [62]. It has further been shown that some communities' economic future is increasingly "uncoupled” from ecological systems and their sustainability is even more complex [63].

Current applied anthropological research on sustainability in arctic and Pacific communities emphasizes sustainable development and competing rationales driving natural resource uses (e.g., [64,65]). Many of these studies focus on single development events, or series of events, in the contemporary world and how indigenous peoples have suffered or thrived due to the impacts of such development, such as the hydroelectric development in Cree territory in Québec [66]. In many cases, development is an inevitable process following a single trajectory, and these studies sought ways to ensure that resource use does not disrupt the relationship between people and the environment. Thus, sustainability in the north means balancing ecological and cultural needs.

Robards and Greenburg [67] argue that village sustainability is more about flexibility and the ability to reinvent cultural and economic identities as markets change, village compositions change, resource abundances shift, and resource management evolves. Villages in the Aleutians are rapidly changing alongside fisheries and climate because of population declines, energy resource development, health challenges, and changes in subsistence and commercial fisheries access. Some communities are more successful than others at maintaining their indigenous space and cultural identity within these changing politics, environments, and economies.

Sustainability must begin with making choices. What are we sustaining? A marine biologist might be concerned over the Right Whale (Eubalaena japonica), since there are only 35 remaining in the Bering Sea making it the most endangered species in the world, and to sustain them will come at the expense of other species. A pollock fisherman will want to ensure steady access to that fishery, which will come with its own set of ecological and social costs. Our research is concerned with sustaining the Aleut, which may come at the expense of others sharing the same space. This is indeed what the Aleut people are concerned with. Sustainability to the Aleut means to be able to live and thrive in their homeland and harvest local species with both subsistence and commercial value. The Aleut are a small-scale society [68] but have not been the only users on the landscape throughout the historic period, and today, local people are no longer the primary harvesters of the region's seafood, although they are of the region's land and sea mammals. There have been waves of rapid population growth, but this is best characterized as rapid user growth, with state and federal managers attempting to slow, consolidate, and restructure fisheries with direct impacts on local communities. Many modern Aleuts enjoy a vigorous wage economy in fisheries, but this is shared with non-local fishermen and controlled by the state and federal regulatory agencies. 
Since large portions of these contemporary responses have historical dimensions, this paper briefly considers sustainability through a longitudinal lens, looking at how people and cultures have survived and adapted on a small island undergoing enormous internal and external changes. The following sections will carry the reader through the major historical time slices of Sanak Island highlighting population shifts, regional interactions, resource use, and Aleut sociocultural responses to changes in order to show how the present situation developed, and the legacies from these previous eras that the modern Aleut people rely on today. Sanak Island saw development of industries followed by recourse to subsistence use from distant villages. Aleuts have been able to move whole communities to follow species and markets, and for convenience such as access to schools, airports, and services. In the case of Sanak, they are sustaining a connection by creating a kind of land trust, a legacy, and a subsistence economy. As will be shown, this land trust requires taking the historical and cultural elements of the formerly occupied Sanak Island and revisiting them in the contemporary context. The people of Sanak are doing this by developing and practicing their own conservation ethics that support the best parts of Sanak’s occupation.

\subsection{Methods}

The Sanak Biocomplexity Project was a broad, transdisciplinary project that integrated the social, natural, and physical sciences to investigate two major problems. First, what have been the roles of prehistoric, historic, and modern Aleut in the structure and functioning of the north Pacific ecosystem and is it possible for that role to continue to viably sustain the communities that live in this ecosystem today? Second, how have major changes in the environment (such as sea level, climate, tsunami, and volcanic eruptions), and social, political, and economic changes (such as migration, colonization, and European expansion), conditioned human social behavior in the context of humanity's role as a key element in the ecosystem engineering and social history of the North Pacific ecosystem [26]. This project was specifically focused to avoid the broad and sweeping generalizations of research such as Jackson et al. [69] that sees local people simply as impacts. The project's goal was to situate local peoples in their ecosystem, and consider those people as integrated parts of a larger system.

In order to investigate the social, political, and economic transitions in sustaining Sanak Island and its region, the project focused on two broad areas of research. The first was literature-based and ranged from the writings of early Russian explorers and traders, British and then American expeditions such as Captain Cook and those associated with the American Fur Seal trade, to more recent documents concerning fisheries, resettlement and land claims. The second was interview based and included unstructured interviews with a broad range of former Sanak residents. These interviews included discussions of genealogy, traditional ecological knowledge, traditional geographies (who lived where and when), subsistence and commercial economies and their locations, political developments, and land claims. These interviews also included discussions of people's perceptions as to the future of Sanak Island, and questions as to how former residents now interact with Sanak Island and its' abandoned communities. The ethnohistoric data and interviews were categorized by time period, topic, sociopolitical event, and quality of sources. The analyses, discussions, and conclusions drawn in this study are a product of our interpretation of the data as a whole. This is a qualitative assessment of a historical process in the context of the theoretical discussions presented above. 


\subsection{Sanak’s Historical and Political Environment}

\subsubsection{Early Encounters with Sanak and the Sea Otter Trade}

Russian merchants learned of Sanak Island and its abundant sea otter grounds from an Aleut slave aboard Stepan Glotov's ship in 1762. In 1771 Ivan Solov'ev brought the first crew of Russians to survey the islands for people and resources, where he found a few hundred Aleut living on a tense frontier between Peninsula Aleuts and the Native peoples of Kodiak Island and Prince William Sound to the east [38]. Solov'ev had already killed a number of Aleuts in the Aleutian Chain as retribution for destroying Russian ships, and he renewed his violent reputation after a short stay on the island. The Russians fled in 1772. Other expeditions, such as Captain Cook and the Billings-Sarychev Expedition, had uneventful encounters with the Sanak Aleut in the following decades, but reports of the wealth of sea otters had sparked great interest in the waters around the islands.

The sea otter was the primary reason for Russian expansion into the Aleutians, and Sanak was at the heart of the concern of the Russian-America Company. Hunters from Unga Island in the Shumagins were dispatched to harvest around Sanak, but after 1808, Sanak hunters were organized into an artel, or work group, of sea otter hunters. These artels were each lead by a Russian baidarshchik (captain) and his Russian and Aleut employees supplied the company. Traditional Aleut hunting methods were used in which hunters would quietly surround the otters in their baidarkas (kayaks) and spear them. High producing hunters, and especially the Creole hunters (those of Russian and Aleut descent), received status within the Russian-America Company.

In 1823, elites of the Russian-America Company moved the Sanak artel to the villages of Belkofski on the Alaska Peninsula fearing that they had overharvested the sea otters in the Sanak waters. Russians imposed conservation measures on sea otter harvesting, which included quotas, timing of harvests, traditional hunting methods, refusals to pay for females and pups, a rotation of hunting grounds, and the relocation of the entire Sanak Aleut population to Belkofski. Hunters continued to travel to Sanak to take sea otters (approximately 10-50 annually) from the southeast shoals and to hunt birds for parkas. Sanak remained uninhabited until after Alaska was purchased by the United States in 1867.

In 1873, the Alaska Commercial Company built a trading post on the northwest end of Sanak Island, which later became the town site of Sanak (often referred to as Company Harbor). The company purchased sea otter pelts from seasonal hunters in the area until the area was depleted of sea otters once again. The company left the island in 1897 and sea otter hunting was officially banned in 1911 as a conservation and rebuilding measure.

The events of this period demonstrate the island's significance during major historical events. It has legendary and iconic elements that allow people to claim that Sanak was a distinctive key historical player, not simply a small island among many. They also help support the notion of a separate cultural identity distinct from the Alaska Peninsula and Aleutian Island Chain Aleut people.

\subsubsection{Cod and Salmon Fisheries}

Pacific cod fishing began in the 1870s in the Aleutian Islands, and schooners from the west coast of North America arrived carrying small dory boats and fishermen [70]. Primarily Scandinavian immigrant cod fishermen came to the region to fish from these dories using hand lines. Codfish stations 
were built beginning in the 1880s, and many of these men began to settle on Sanak and nearby cod fishing sites and married Aleut women. Stations for salting cod and storing them in barrels were established in the early 20th century at Company Harbor (site of Sanak village), Moffats Cove, Pauloff Harbor and Johnson Harbor on Sanak, as well as several on the Alaska Peninsula and Shumagin Islands. The region's codfish fishery supplied approximately one-third of the total Alaska catch. Cod began to disappear from the waters around Sanak after 1915 and shore stations closed down one by one.

Codfish companies were largely gone from the region by the 1930s. The majority of Aleut families living in the current communities of King Cove, Sand Point, False Pass and Nelson Lagoon trace ancestors to the island during this time. They also credit their current engagement with commercial fishing to these European ancestors who brought an intensive fishing lifestyle to the area and changed the regional economy [7]. In this way, contemporary Aleut culture in this region of the north Pacific was born on Sanak. Codfishing continues around the island, but the 1930s crash of the cod population undermined the ability of these fishermen to stay on the island.

In the 1910s, salmon canneries were built by the Pacific American Fisheries Company on the Alaska Peninsula. Residents of Sanak started salmon fishing more intensely than only for subsistence levels and the surplus they produced was used to barter for groceries and supplies. They fished for salmon in small streams around the island, and split and salted salmon, storing them in barrels. These were small family operations, but their fishing practices had short-term negative effects on the local salmon runs [26]. These families eventually had to relocate to their present villages on the Peninsula to engage in better fishing and be near the salmon canneries.

\subsubsection{Cattle Ranching and Fox Farming}

Coastal peoples do not often have significant land resources at their disposal, but the Aleut have intentionally cultivated cattle for food. Russian fur traders had brought cattle to the Aleutian Islands in the early 19th century to help support their operations and the Russian priest Veniaminov identified Sanak Island as a key location for future cattle ranching in the Russian colonies [41]. The introduction of cattle to Sanak did not occur until during the cod industry when fishermen brought a few cattle each year for milk and meat, and let them roam free at the end of a fishing season. A former teacher counted 200 wild cattle on Sanak in 1930. Several Scandinavian-Aleut families soon brought cattle to the island to try to start an export business. These operations were never fully established, and the cattle supplemented their subsistence lifestyle of hunting and fishing, and salting salmon and codfish. In the 1950s, another attempt was made at a cattle operation with both meat and dairy breeds. Success of the ranch was minimal but there were customers in other Aleutian villages. A mixture of these breeds remain on the island and are hunted by residents of Sand Point, King Cove and False Pass as subsistence beef, and continue to provide a substantial, desirable food source.

Fox farming was introduced to the island around the turn of the twentieth century. Foxes had previously been recorded on the island by Russians. In 1779, Ivan Kobelev reported black-brown foxes, cross foxes and red foxes on Sanak. The Russians may have brought breeding pairs with them, but there are no further reports until the early twentieth century when Scandinavians and Aleuts began farming foxes. These fox farmers used the smaller islands around Sanak as natural pens, trapping them 
when needed in the winter when the pelts were thickest, and shipping the skins to buyers. They built small cabins on these islands, which were washed away, along with all the foxes, in a huge 1946 tsunami. The main island of Sanak had foxes until 2007 when the Sanak Corporation applied for funds to exterminate them with a goal of restoring native bird populations. These efforts will be revisited below as part of the land trust.

\subsubsection{Other 20th Century Events}

Army and Navy personnel were stationed on Sanak and Caton Islands during World War II. The residents were not evacuated for the duration of the war like many other Aleut villages. Instead, several young men ran supply and transport boats between Sanak and other outposts. Military personnel moved off the island after the war. Although these are marine-based cultures, testimony given at federal hearings after the forceful relocation of Aleut people during World War II clearly demonstrates the importance of place and landscape to coastal people [71].

The residents lived a subsistence lifestyle until the economic centers of Sand Point, King Cove, and False Pass became attractive relocation sites. One by one, families moved to these communities to enter commercial fisheries, live closer to fish processing plants, and attend schools. The cattle operation dwindled and the caretakers, the last residents, left the island in 1980.

Sanak Island is now managed by its Aleut landlords as a subsistence and recreational base and as a focus of tribal identity. Past development processes have shown a series of external agents modifying the economy and exploiting local people. Modern day Sanak Aleut regard many of these economic processes as positive, part of the natural, cultural and historical elements of environment and society that is their heritage. Their challenge today is in maintaining positive connections to an uninhabited place in a region where land has rarely been the focus of the local economy. Current efforts are described below.

\section{Building a Cultural Land Trust}

Land trusts are typically conservancies, private nonprofit organizations that preserve or protect land for public use and enjoyment, oftentimes for scenic and recreational uses. Cultural land trusts are heritage-based, where local peoples have a specific attachment to a defined landscape and history. Cultural land trusts are a relatively new concept, but the few examples in the literature are born from the wilderness conservancy model that preserves heritage landscapes because of heritage [72]. We see the cultural land trust very differently. Here the cultural land trust is use-based; it creates a sense of place for peoples who have been dislocated from their homeland, and provides a means of access to the landscapes of their heritage. In order to construct the concept of a cultural land trust, we must be respectful of this particular context. Local people take the historical and cultural elements from when the island was occupied, expand on these histories by supporting archaeological and historical documentation, support ecological work that inventories the biodiversity of the island and human-natural interconnections, and actively create a conservation ethic that reinforces certain uses of the island. Below we will show how these histories feed into the present as people support old traditions and create new ones, emphasize iconic elements of life on Sanak, encourage substantial Aleut community participation in using the land and resources of Sanak, facilitate research that 
documents their ancestral heritage and biological significance, and support strong leadership and the generational transfer of control and responsibility for the island's ecology, economy and culture.

\subsection{Land Selection, Tribe, and Heritage}

Tribes have existed in Alaska for centuries as distinct ethnic and cultural entities. The formation of federally recognized tribes, however, is a recent process confirmed by Congressional acts, and the State of Alaska recognizes these tribes as having authority and responsibility to their members. Most tribes in Alaska are located within the village the people inhabited at the time of official tribal federal recognition, which occurred primarily in the 1980s. A second development that cemented power and identity was the Alaska Native Claims Settlement Act (ANCSA) in 1971 in which indigenous claims to land had to be settled before the state and federal governments could sell oil leases and develop large petroleum reserves. The passage of ANCSA included the definition of a village as any community with a population of 25 or more on the 1970 U.S. Census. Traditional Native lands are not retained by the traditional government of the Native group. Alaska Natives negotiated lands that would remain in their control but tribal governments were not appointed to administer these lands. Instead, regional and village corporations were created in ANCSA that took over title and management of Native lands which could develop them for the benefit of their shareholders [73,74]. Village corporations are also largely based on the village sites at the time of legislation. The Sanak Corporation was created at this time to receive lands and funds.

Land selection could be interpreted as a type of land trust at the time. They made land selections based both on heritage and historical use, and perceptions of future use. Some land claims were made in areas where it was expected that the US Government would attempt to buy back some of the claims for Wilderness areas, generating cash for the corporation. Others were made on lands that had high potential for natural resource extraction. But many village corporations simply selected lands that their ancestors had occupied and that were meaningful places for them to hold on to.

In the eastern Aleutian region, there are three tribes that are no longer located in their traditional village lands, with all tribal members living in other communities: the Pauloff Harbor Tribe and the Unga Tribe are located in Sand Point, Alaska, and the Belkofski Tribe is located in King Cove, Alaska. These three villages were struggling to retain residents at the time of ANCSA and Tribal Recognition. The economic centers in fishing had shifted to Sand Point and King Cove, and their residents slowly abandoned their village homes for these larger communities. Each of these tribes works to maintain connections to their former villages culturally and generationally by supporting research projects, applying for caretaking funds, and using and appreciating their ancestral homelands. Kearney [19] highlights population movement and its concomitant adjustments in the context of globalization and deterritorialization, where capitalist enterprises relocate operations, and can lead to the detachment of communities and identities from local places. In this same light, centers of production moved off of Sanak and other locations and people coalesced around these new bases, creating new villages. Control of the land is retained by its former residents and their descendants through village corporations. Yet tribal recognition based upon villages somewhat divided ethnically related people and tied their identity to a particular location. Residents had the option to choose their tribe if they had multiple identities, and could only choose one. Members of the Pauloff Harbor Tribe are related to 
members of other tribes in the region; they share a similar Scandinavian-Russian-Aleut heritage, and share ancestors. In Sand Point, a section of town was named Little Sanak, where the majority of its residents had relocated and attempted to maintain some geographic distinction. Today Sanak Islanders are dispersed across several villages and the city of Anchorage, but still identify as tribal members. Many anthropologists critique community descriptions of bounded places as false, or "narrative devices" of convenience (e.g., [15,75]), but this tribe uses this enclosed community as its own narrative device as a focus of identity.

The Pauloff Harbor Tribe has a young, vibrant leadership that works to maintain cohesion and identity under these circumstances and redefine the island's value for its people. It is most successful in doing so by attributing the fishing heritage of the modern Aleut to their Euro-American ancestors of Sanak and opening up Sanak Island to multiple users in the region. The tribe takes this significant iconic piece of Sanak's history as the foundation for modern Aleut culture and shares the island with the larger Aleut community.

\subsection{Subsistence Species Diversity and Availability}

Sanak is an importance subsistence harvesting location, and locals hunt ducks and cattle, and fish its streams and ocean for salmon, trout, cod, and halibut. The beaches provide bidarkis (black katy chitons or Katherina tunicata), urchins, and clams, among many wild foods. Nests in the cliffs are excellent places to harvest gull eggs. Sanak Islanders have their own conservation ethic related to these resources that complements their subsistence lifestyle and uses for the island.

A strong theme in ecological anthropology states that the best way to conserve natural resources is to protect indigenous peoples, their practices, and environmental knowledge, who are the best stewards of the environment in which they live (e.g., [76-78]). A polarized alternative argument states that indigenous peoples actively modify their environment for their own short-term gains at any cost to the environment $[79,80]$. A middle ground approach suggests that while people rarely set out to conserve their resources, sustainable use by small-scale indigenous societies is widespread and may even preserve biodiversity [81]. The Aleutian environment is a mixture of intensely harvested natural resources subject to a wide range of users, both resident and transient; resources that are purely subsistence harvested at low levels; and resources not used by humans at all but are part of these broader interactions. In this case, the Aleut caretakers are selecting species for conservation that are useful to the people, supporting their vision of Sanak's role in their lives. Their vision and actions do not conform to those of the U.S. Fish and Wildlife Service, and likely do not conform to those of many environmental organizations, but they are shaping the land for their own needs. Sanak had an active cattle ranch, slaughterhouse, and meat packaging facility until the 1950s, and management of the cattle continued after this time. Scottish Highlander breeds were introduced in the 1970s. The animals are a feral breed mixture today and are loosely managed for subsistence. Although owned by the Sanak Corporation, many non-member Aleut hunt these cattle. Hunters will notify the Corporation when they are embarking on a trip to the island. The U.S. Fish and Wildlife Service removed the cattle from other islands in the Sanak group, such as Caton Island, because they felt they were destroying vegetation and habitat for native species. Local people were upset that this was a waste of subsistence resources. In survey data from 2009 from a separate project, four hunters from False Pass reported taking 
13 cattle off Sanak in a single calendar year. This translated to 4550 pounds of usable meat that was shared among all 15 households in False Pass, and at least two households in Nelson Lagoon, and two more in King Cove. This meat was also traded for crab with fishermen from the Bering Sea fleet passing through False Pass. That project did not include household surveys in King Cove and Sand Point, but anecdotal information has indicated that substantially higher rates of harvest and sharing of Sanak beef are found in these two larger communities [3]. Furthermore, the island is often used to train younger hunters who may later target caribou on the Alaska Peninsula. This ethic of keeping relatively open access ties more than just tribal members to the land, and keeps the island a valuable resource for all villages.

The Aleut people have their own sense of invasive species and island restoration and, in 2006, they applied for and received U.S. Fish and Wildlife funds to remove the foxes from Sanak Island. The premise was the same as the cattle removal on other islands: removing species that are not native to the island so that the native species will return. However, the fox removal is for bird restoration so that seabird and shorebird populations will increase on the island, which can then be hunted by the Aleut. It was also meant to increase the potential for seagull egg harvesting in more places across the island. Conserving natural resources for them involved choosing what to conserve. Cattle are included because they have local value but foxes no longer do. These are local choices supporting local needs.

\subsection{Protection of sites of Archaeological and Biological Significance}

The Sanak Corporation and Pauloff Harbor Tribe supported and facilitated archaeological and ecological work on the islands in 2002, 2004, 2006 and 2007. From this work, they can now formally draw on their 7000 years of Aleut occupation on the island as a source of identity and continuity. Our research team documented all the archaeological sites on the island and provided a free publication to Sanak Corporation and Pauloff Harbor Tribal members that inventories the islands cultural and biological resources and shows their interconnections [3]. The publication also pulls together all pieces of history by summarizing the ethnohistorical documents, historic and modern photographs, and interviews. Treating the island as a heritage site, in which the cultural, natural and historical elements are documented, appreciated, and relived, will ideally carry through from one generation to the next.

The Pauloff Harbor Tribe had strong concerns about waste on the island and its potentially hazardous effects on the subsistence resources there. There were old batteries and drums of hazardous materials, for example, rusting and eroding into the tundra around the villages and former military site. The Tribe applied for and received an EPA-IGAP (Environmental Protection Agency-Indian General Assistance Program) grant in 2002 to remove batteries, drums, and other environmental hazards that may harm subsistence foods to protect the health of people using the island. A team of trained workers from the tribe and the EPA worked to remove waste and reduce environmental risk to the island's users. These funds have been renewed in recent years to continue this important work.

\subsection{Resilience and Flexibility}

Mobility was a key strategy for these semi-sedentary peoples for their 7000 year history. Russian and American colonization forcefully continued this pattern. The Sanak Corporation and Pauloff Harbor Tribe recognize the flexibility of population and development. They have seen large 
and small scale economic developments built on their island's resources, and they have seen these developments dismantled, relocated, and replaced. These were necessary movements and changes in order for the Aleut society, culture, and local economy to continue to thrive in their homeland.

While it seems unlikely in the near term, former residents of Sanak discuss the possibility of recolonizing the island in the future. This could begin, they say, with seasonal hunting and fishing cabins, including lodges to host sport hunters, and which may grow into longer residences. The Corporation is rebuilding houses so that people can stay on the island during hunting trips. They are also constructing or improving old roads so that travel around the island is easier. When asked if they would move back if the opportunities and infrastructure were there, many said they would. In this way, island occupation is still a desire and a goal for many, keeping it on the horizon as an attainable homeland again in the future.

\section{Conclusions}

The Aleutian Islands of Alaska are places where the forces of exploration, colonialism, imperialism, mercantile capitalism, and the influxes of new people from across the globe have generated a unique society. Different histories coexist throughout the island chain, reflecting different rates of absorption and resistance to the modernity that washed up on its shores. There have been multiple frontiers in the Aleutians, spanning generations, and tied to booms in global commodities. New people, new technologies, new desires, new forms of social organization accompanied each of these shifts, marked by the resources they extracted, the markets where they traded, and the biophysical effects to the landscape and ocean. People appeared and disappeared, such as the promyshlenniki (Russian fur hunters), missionaries, transient fishermen; others stayed and became local, like many Scandinavian fishermen. Newcomers interacted with the people already there, essentially changing both. The Aleut have experienced major transformations, yet have retained core elements of character. Sanak can be seen as a "vertical slice" of the greater Aleutian history and modern story. This is a vibrant history that the modern Sanak caretakers draw upon when making their own attachments to the island.

From rapid industrialization at Russian contact, to local barter systems with distant merchants, to the development of a Scandinavian-Aleut fishing lifestyle, to subsistence style land use, Aleuts of Sanak Island were part of open economic systems. Sanak has experienced different industries and strategies, each with their own variables of human effort, landscape and resource effects, population dynamics, technology, and sociopolitical regulation. Here development does not follow a single trajectory. The Aleut require flexibility to achieve resilience and sustainability for the land, resources, and for themselves.

Extractive economies in sea otter hunting and codfishing were driven by distant markets. Cattle ranching was less successful because of market forces. This was supplemented by barter in salted cod and salmon to a Seattle company for food and supplies. Barter systems usually indicated a political value as well as economic value of the exchange partnership. The return, if you will, to a purely subsistence-based use of the land and resources is facilitated today by the use of large commercial boats, all terrain vehicles, and rifles, acquired from revenue from commercial fishing, and cattle are seen as part of the landscape and a viable food source for local Aleuts. The resources of Sanak feed more than its own tribal and corporate members, and most households have some Sanak beef 
in their freezers. In this way, Sanak serves as a cultural land trust for the people of the region, where there is corporate ownership, governance, and resource use control for a community. Land is not equally important to all societies, but the coastal, marine-based Aleut still require significant land holdings as sources of identity, power and food. Through such efforts as rebuilding houses and environmental cleanup, the Aleut are reifying place and identity through local investments. Sanak Island is an important social unit with attached meanings and values.

Most villagers in Alaska still live in the locations of their traditional villages since the development of corporations, but three tribes in the study region are no longer on their traditional sites: Belkofski, Unga, and Pauloff Harbor. Like the Pauloff Harbor Tribe and the Sanak Corporation, these two other tribes and associated village corporations similarly maintain their former villages and lands as cultural land trusts. On Sanak Island, there are no minerals, no timber, and the only land-based resource (cattle) is used as a subsistence resource. The maintenance of Sanak Island is cultural. It is cared for as a place of identity and heritage. The Aleut of Sanak Island see cultural resilience and sustainability in this sense of place, in their ability to visit, care take, and maintain these now abandoned communities and landscapes. Sustainability studies in the Arctic, Pacific, and around the world are most often place-based. How do we maintain the viability, location, and infrastructure of traditional communities? In many cases this is not possible even though millions of dollars are allocated every year to keep indigenous peoples in their traditional villages. For the Sanak Islanders, they have solved this through their own actions. The Sanak Aleut have figured out ways to be place-focused but not place-based, by sustaining their traditional connections to their communities without actually living in those communities. We believe that this will be a model replicated throughout the world as globalization and global change impact local indigenous peoples.

\section{Acknowledgments}

The authors wish to thank the Sanak Corporation, Pauloff Harbor Tribe, and former residents of the Sanak Islands. This work is supported by the National Science Foundation awards NSF BE/CNH 0508101, NSF ARC 0326584, NSF ARC 9996415, and NSF BCS 0119743. All opinions, findings, and conclusions or recommendations expressed in this material are those of the authors and do not necessarily reflect the views of the National Science Foundation.

\section{Conflicts of Interest}

The authors declare no conflict of interest.

\section{References}

1. Lantis, M. Aleut. In Handbook of North American Indians, Volume 5: Arctic; Damas, D., Ed.; Smithsonian Institution: Washington, DC, USA,1984; pp. 161-184.

2. Laughlin, W.S. Aleuts: Survivors of the Bering Land Bridge; Holt, Rinehart and Winston: New York, NY, USA, 1980.

3. Reedy-Maschner, K.L.; Maschner, H.D.G. Sanak Island, Alaska: A Natural and Cultural History; Idaho Museum of Natural History: Pocatello, ID, USA, 2012. 
4. McCartney, A.P. Prehistory of the Aleutian Region. In Handbook of North American Indians; Damas, D., Ed.; Smithsonian Institution: Washington, DC, USA, 1984; Volume 5, pp. 119-135.

5. Maschner, H.D.G. Archaeology of the North Pacific. In The Oxford Handbook of North American Archaeology; Pauketat, T., Ed.; Oxford University Press: New York, NY, USA, 2012; pp. 135-145.

6. Maschner, H.D.G.; Reedy-Maschner, K.L. Aleuts and the sea: Archaeology on the Alaska Peninsula is helping indigenous fishermen maintain ancient traditions. Archaeology 2005, 58, 63-70.

7. Reedy-Maschner, K. Aleut identities: Tradition and Modernity in an Indigenous Fishery; McGill-Queen’s University Press: Montreal, QC, Canada, 2010.

8. Reedy-Maschner, K. Where did all the Aleut men go? Aleut male attrition and related patterns in Aleutian historical demography and social organization. Hum. Biol. 2010, 82, 583-611.

9. Crate, S.A.; Nuttall, M. Anthropology and Climate Change: From Encounters to Actions; Left Coast Press Inc.: Walnut Creek, CA, USA, 2009.

10. Hoffman, S.; Oliver-Smith, A. Catastrophe and Culture: The Anthropology of Disaster; School of American Research: Santa Fe, NM, USA, 2002.

11. Oliver-Smith, A. Development and Dispossession: The Crisis of Forced Displacement and Resettlement; School of American Research: Santa Fe, NM, USA, 2009.

12. Macinko, S. Fishing communities as special places: The problem of place in contemporary fisheries management. Ocean Coast. Law J. 2006, 13, 71-94.

13. Cruikshank, J. Life Lived Like a Story: Life Stories of Three Yukon Native Elders; University of Nebraska Press: Lincoln, NE, USA, 1990.

14. Feld, S.; Basso, K. Senses of Place; School of American Research: Albuquerque, NM, USA, 1996.

15. Gupta, A.; Ferguson, J. Culture, Power, Place: Explorations in Critical Anthropology; Duke University Press: London, UK, 1997.

16. Low, S.; Lawrence-Zúñiga, D. The Anthropology of Space and Place: Locating Culture; Blackwell: London, UK, 2003.

17. Thornton, T. Being and Place Among the Tlingit; University of Washington Press: Seattle, WA, USA, 2007.

18. Appadurai, A. Global Ethnoscapes: Notes and Queries for a Transnational Anthropology. In Recapturing Anthropology: Working in the Present; Fox, R.G., Ed.; School of American Research Press: Santa Fe, NM, USA, 1991; pp. 48-65.

19. Kearney, M. The local and the global: The anthropology of globalization and transnationalism. Annu. Rev. Anthropol. 1995, 24, 547-565.

20. Kingston, D. Returning: Twentieth Century Performances of the King Island Wolf Dance; University of Alaska: Fairbanks, AK, USA, 1999.

21. Crate, S.A. Climate Change and Human Mobility in Indigenous Communities of the Russian North. In Brookings-LSE; Brookings-Bern Project on Internal Displacement: Hanover, PA, USA, 2013; p. 58.

22. Marino, E. The long history of environmental migration: Assessing vulnerability construction and obstacles to successful relocation in Shishmaref, Alaska. Global Environ. Change 2012, 22, 374-381.

23. Kingston, D.; Marino, E. Twice removed: king islanders' experience of “community” through two relocations. Hum. Organ. 2010, 69, 119-128. 
24. Berkes, F.; Colding, J.; Folke, C. Navigating Social-Ecological Systems: Building Resilience for Complexity and Change; Cambridge University Press: Cambridge, UK, 2003.

25. Gunderson, L.H.; Holling, C.S. Panarchy: Understanding Transformations in Human and Natural Systems; Island Press: Washington, DC, USA, 2002.

26. Maschner, H.D.G.; Betts, M.W.; Cornell, J.; Dunne, J.A.; Finney, B.; Huntly, N.; Jordan, J.W.; King, A.A.; Misarti, N.; Reedy-Maschner, K.L.; et al. An introduction to the biocomplexity of Sanak Island, western Gulf of Alaska. Pac. Sci. 2009, 63, 673-709.

27. Maschner, H.D.G.; Finney, B.P.; Jordan, J.W.; Misarti, N.; Tews, A.; Knudsen, G.L. Did the North PACIFIC Ecosystem Collapse in AD 1000? In The Northern World AD 900-1400: The Dynamics of Climate, Economy, and Politics in Hemispheric Perspective; Maschner, H.D.G., Mason, O.K., McGhee, R., Eds.; University of Utah Press: Salt Lake City, UT, USA, 2009; pp. 33-57.

28. Maschner, H.D.G.; Trites, A.W.; Reedy-Maschner, K.L.; Matthew, B. The decline of Steller sea lions (Eumetopias jubatus) in the North Pacific: Insights from indigenous people, ethnohistoric records and archaeological data. Fish Fish. 2013, doi:10.1111/faf.12038.

29. Misarti, N.; Finney, B.; Maschner, H.D.G.; Whooller, M.J. Changes in northeast Pacific marine ecosystems over the last 4500 years: Evidence from stable isotope analysis of bone collagen from archeological middens. Holocene 2009, 19, 1139-1151.

30. Betts, M.W.; Maschner, H.D.G.; Lech, V. A 4500 Year Time-Series of Otariid Abundance on Sanak Island, Western Gulf of Alaska. In Human Impacts on Seals, Sea Lions, and Sea Otters: Integrating Archaeology and Ecology in the Northeast Pacific; Braje, T., Rick, T., Eds.; University of California Press: Berkley, CA, USA, 2011; pp. 93-110.

31. Betts, M.W.; Maschner, H.D.G.; Clark, D.S. Zooarchaeology of the 'Fish that Stops': Using Archaeofaunas to Construct Long-Term Time Series of Atlantic and Pacific Cod Populations. In The Archaeology of North Pacific Fisheries; Moss, M., Cannon, A., Eds.; University of Alaska Press: Fairbanks, AK, USA, 2011; pp. 171-194.

32. Maschner, H.D.G.; Betts, M.W.; Reedy-Maschner, K.; Trites, A.W. A 4500 year time series of Pacific Cod (Gadus macrocephalus): Archaeology, regime shifts, and sustainable fisheries. Fish. Bull. 2008, 106, 386-394.

33. Lech, V.; Betts, M.W.; Maschner, H.D.G. An Analysis of Seal, Sea Lion, and Sea Otter Consumption Patterns on Sanak Island, Alaska: A 4500 Year Record on Aleut Consumer Behavior. In Human Impacts on Seals, Sea Lions, and Sea Otters: Integrating Archaeology and Ecology in the Northeast Pacific; Braje, T., Rick, T., Eds.; University of California Press: Berkley, CA, USA, 2011; pp. 111-128.

34. Bergsland, K.; Dirks, M. Unangam Ungiikangin kayux Tunusangin; Unangam Uniikangis ama Tunuzangis; Aleut Tales and Narratives: Collected 1909-1910 by Waldemar Jochelson; Alaska Native Language Center: Fairbanks, AK, USA, 1990.

35. Black, L.T. Atka: An Ethnohistory of the Western Aleutian Islands. In Alaska History; Pierce, R.A., Ed.; The Limestone Press: Kingston, ON, Canada, 1984; Volume 24.

36. Black, L.T. The Round the World Voyage of Hieromonk Gideon 1803-1809; The Limestone Press: Kingston, ON, Canada, 1989. 
37. Black, L.T. Glory Remembered: Wooden Headgear of Alaska Sea Hunters; Alaska State Museums: Sitka, AK, USA, 1991.

38. Black, L.T.; McGowan, S.; Jacka, J.; Taksami, N.; Wright, M. The History and Ethnohistory of the Aleutians East Borough; University of Alaska Press: Fairbanks, AK, USA, 1999.

39. Jochelson, W. History, Ethnology, and Anthropology of the Aleut; Carnegie Institution of Washington: Washington, DC, USA, 1933.

40. Townsend, J.B. Pre-Contact Political Organization and Slavery in Aleut Societies. In The Development of Political Organization in Native North America; Tooker, E., Fried, M.H., Eds.; The American Ethnological Society: Washington, DC, USA, 1983; pp. 120-132.

41. Veniaminov, I. Notes on the Islands of the Unalaska District; The Limestone Press: Kingston, ON, Canada, 1984.

42. Jones, D.M. A Study of Social and Economic Problems in Unalaska: An Aleut Village; University of California: Berkeley, CA, USA, 1969.

43. Jones, D.M. Aleuts in Transition: A Comparison of Two Villages; University of Washington Press: Seattle, WA, USA, 1976.

44. Khlebnikov, K.T. Notes on Russian America: Parts II-V: Kad'iak, Unalashka, Atkha, the Pribylovs; The Limestone Press: Fairbanks, AK, USA, 1994.

45. Applegate, S. Population and Resources of Alaska at the 11th Census: 1890; US Government Printing Office: Washington, DC, USA, 1893.

46. Elliott, H.W. Our Arctic Province, Alaska and the Seal Islands; Charles Scribner's Sons: New York, NY, USA, 1887.

47. Hooper, C.L. A Report on the Sea-Otter Banks of Alaska; Government Printing Office: Washington, DC, USA, 1897.

48. Campbell, A. A Voyage Round the World from 1806 to 1812; N. Israel and Da Capo Presses: Amsterdam, The Netherlands, 1969; Volume 50.

49. Appadurai, A. Putting hierarchy in its place. Cult. Anthropol. 1998, 3, 36-49.

50. Gupta, A.; Ferguson, J. Beyond culture: Space, identity and the politics of difference. Cult. Anthropol. 1992, 7, 6-23.

51. Ganapathy, S. Imagining Alaska: Local and translocal engagements with place. Am. Anthropol. 2013, 115, 96-111.

52. Sahlins, M. Notes on the Original Affluent Society. In Man the Hunter; Lee, R.B., DeVore, I., Eds.; Aldine Publishing Company: New York, NY, USA, 1968; pp. 85-89.

53. Bird-David, N. The giving environment: Another perspective on the economic system of hunter-gatherers. Curr. Anthropol. 1990, 31, 189-196.

54. Rappaport, R.A. Pigs for the Ancestors; Yale University Press: New Haven, CT, USA, 1968.

55. Yesner, D.R. Archaeological Applications of Optimal Foraging Theory: Harvest Strategies of Aleut Hunter-Gatherers. In Hunter-Gatherer Foraging Strategies; Winterhalder, B., Smith, E., Eds.; University of Chicago Press: Chicago, IL, USA, 1981; pp. 148-170.

56. Failla, J.T. The Original Ecologists! Available online: http://news.google.com/ newspapers?nid=1928\&dat=19740726\&id=23ggAAAAIBAJ\&sjid=iWcFAAAAIBAJ\&pg=1761, 4042873 (accessed on 25 July 2013). 
57. Brosius, J.P.; Tsing, A.L.; Zerner, C. Representing communities: Histories and the politics of community-based natural resource management. Soc. Nat. Resour. 1998, 11, 157-168.

58. Hodgson, D. Introduction: Comparative perspectives on the indigenous rights movement in Africa and the Americas. Am. Anthropol. 2002, 104, 1037-1049.

59. Li, T. Articulating indigenous identity in Indonesia: Resource politics and the Tribal Slot. Comp. Stud. Soc. Hist. 2000, 42, 149-179.

60. Crate, S.A. Investigating local definitions of sustainability in the Arctic: Insights from post-Soviet Sakha Villages. Arctic 2006, 59, 294-310.

61. Kofinas, G.; Braund, S. Defining arctic community sustainability: A background paper prepared for the National Science Foundation Sustainability of Arctic Communities Project. Available online: http://www.iser.uaa.alaska.edu/Publications/1998_12-DefiningArcticCommunitySustainability.pdf (accessed on 25 July 2013).

62. Reedy-Maschner, K.L. Deprivations Amid Abundance: The Role of Salmon and "Other Natural Resources” in Sustaining Aleut Villages. In Keystone Nations: Indigenous Peoples and Salmon across the Northern Pacific; Brooks, J., Colombi, B., Eds.; School of Advanced Research: Santa Fe, NM, USA, 2012.

63. Huntington, H.P.; Kruse, S.A.; Scholz, A.J. Demographic and environmental conditions are uncoupled in the social-ecological system of the Pribilof Islands. Polar Res. 2009, 28, 119-128.

64. Chance, N.; Andreeva, E. Sustainability, equity, and natural-resource development in northwest Siberia and arctic Alaska. Hum. Ecol. 1995, 23, 217-240.

65. Vitebsky, P. Gas, environmentalism and native anxieties in the Soviet Arctic: The case of Yamal peninsula. Polar Rec. 1990, 156, 19-26.

66. Feit, H. Hunting and the Quest for Power: The James Bay Cree and Whiteman Development. In Native Peoples: The Canadian Experience; Morrison, R.B., Wilson, C.R., Eds.; Oxford University Press: Oxford, UK, 2004.

67. Robards, M.; Greenberg, J. Global constraints on rural fishing communities: Whose resilience is it anyway? Fish Fish. 2007, 8, 14-30.

68. Bodley, J. Anthropology and Contemporary Human Problems, 3rd ed.; Mayfield Publishing: Mountain View, CA, USA, 1996.

69. Jackson, J.B.C.; Kirby, M.X.; Berger, W.H.; Bjorndal, K.A.; Botsford, L.W.; Bourque, B.J.; Bradbury, R.H.; Cooke, R.; Erlandson, J.; Estes, J.A.; et al. Historical overfishing and the recent collapse of coastal ecosystems. Science 2001, 293, 629-638.

70. Shields, E. Capt. Salt of the Sea: The Pacific Coast Cod Fishery and the Last Days of Sail; Pacific Heritage Press: Marina, CA,USA, 2001.

71. Kohlhoff, D. When the Wind was a River: Aleut Evacuation in World War II; University of Washington Press: Seattle, WA, USA, 1995.

72. Rosales, H. The intertribal Sinkyone wilderness: Ten tribes reclaiming, stewarding, and restoring ancestral lands. Int. J. Wilderness 2010, 16, 8-12.

73. Berger, T.R. Village Journey: The Report of the Alaska Native Review Commission; Hill and Wang: New York, NY, USA, 1985.

74. Case, D.S. Alaska Natives and American Laws; University of Alaska Press: Fairbanks, AK, USA, 2000. 
75. Creed, G. The Seductions of Community: Emancipations, Oppressions, Quandaries; School of American Research Press: Santa Fe, NM, USA, 2006.

76. Berkes, F. Sacred Ecology: Traditional Ecological Knowledge and Resource Management; Taylor \& Francis: Philadelphia, PA, USA, 1999.

77. Brosius, J.P. Endangered forest, endangered people: Environmentalists' representations of indigenous knowledge. Hum. Ecol. 1997, 25, 47-69.

78. Stevens, S. Conservation Through Cultural Survival: Indigenous Peoples and Protected Areas; Island Press: Washington, DC, USA, 1997.

79. Brightman, R. Conservation and Resource Depletion: The Case of the Boreal Forest Algonquians. In The Question of the Commons: The Culture and Ecology of Communal Resources; McCay, B., Acheson, J., Eds.; University of Arizona Press: Tuscon, AZ, USA, 1987; pp. 131-132.

80. Krech, S., III. The Ecological Indian; W.W. Norton \& Company: New York, NY, USA, 1999.

81. Smith, E.A.; Wishnie, M. Conservation and subsistence in small-scale societies. Annu. Rev. Anthropol. 2000, 29, 493-524.

(C) 2013 by the authors; licensee MDPI, Basel, Switzerland. This article is an open access article distributed under the terms and conditions of the Creative Commons Attribution license (http://creativecommons.org/licenses/by/3.0/). 